\title{
Favorable of grouted micropiles for the load transfer in weak sandy soils
}

\author{
Ahmed Al-Obaidi ${ }^{1, *}$, and Ansam Al-Karawi ${ }^{2}$ \\ ${ }^{1}$ Tikrit University, Tikrit, Iraq \\ ${ }^{2}$ Cihan University, Erbeil, Iraq
}

\begin{abstract}
Micropiles are defined as small diameter piles, implemented as a cast-in-place replacement or injected grout. Generally assumed with a diameter less than $300 \mathrm{~mm}$. The axial capacity of micropiles develops primarily through the bond between gravity grouted (Type A) or post grouted (Type B, C or D) and soil in bonded zone of the micropile. Because of this, micropiles are useful in a variety of applications. Micropiles (Type D) indicate a two-step process of grouting, neat cement grout is placed under gravity head, then, additional grout is injected via a sleeved grout pipe at a specified pressure. In this research, a numerical model was developed to simulate the properties of the micropile (Type D), in addition to micropile (Type A). A general finite element program ABAQUS was selected for the numerical analysis method and for generating the solution. The parameters that affect the load transfer and ultimate capacity of the micropile foundation, which includes micropile length, diameter, grouted length and weak soil type, were investigated. The main results show that the pressure grouting micropile provides better load transfer mechanism as it makes surrounding soil strength to be fully mobilized upon axial loading. Micropiles (Type D) show more favorable in a capacity where the increment range is up to $50 \%$ as compared with ground grouted micropiles (Type A). In addition, the results indicate that the ultimate capacity of micropile increases as the grouted length increases.
\end{abstract}

\section{Introduction}

Micropiles first appeared as a cost effective way to rehabilitation of existing historical structures. Recently, micropiles have gained popularity all over the world and are being used for buildings, bridges, antenna towers, slope stability and residential construction. Micropiles is superior in case of difficult drilling conditions where other deep foundation methods are not reasonable and consist of any combination of rebar, grout, hollow bar, steel pin, and steel casing.

Typical micropile design procedures are covered by Federal Highway Administration [1], where the bond stress method was developed solely. The use of finite element method for the micropile analysis was adopted by many authors, [2], [3], and [4]. Simulation of micropiles Type D differs from micropiles Type A in which that micropile Type D indicates a two-steps process of grouting. The primary grout is placed under gravity, and after hardening of initially placed grout, additional grout is injected via tube a Manchette at a pressure of 2 to $8 \mathrm{MPa}$. A packer may be used so that specific levels can be treated several times, if required. In cohesionless soil, the pressure grout, a certain amount of permeation and replacement to loosened soil takes place and causes the formation of cake-like cement paste along the grout soil interface that improves the bond. Pressure grouting also appears to cause a re-compaction or re-densification of the soil around the borehole, [5]. The effective micropile diameter (after post grouting) depends on magnitude of grouting pressure and type of soils; the radial expansion occurs so drilled hole diameter extend from (D) to ( $\alpha \mathrm{c} D)$

The effective diameter is estimated using a correction factor $(\alpha c)$ [6] that allows for radial expansion due to pressure grouting typical values are shown in Table (1). Many researchers suggested the form of micropiles after the execution in the site with various shapes, as illustrated in the Fig. (1).

In the present study, a general finite element program ABAQUS/CAE is selected to appraise the capacity of micropile in the weak soil, involving the soil-structure interaction which is considered as important topic in developing the performance of the different type of micropiles.

\section{Parametric study}

In the analysis of micropile, the axisymmetric model is built to simulate the soil-micropiles interaction and load

* Corresponding author: dr.obaidi.a.h@tu.edi.iq 
transfer of two micropiles type A and D in weak soil. Also, the micropiles case one under axial loading were used with different lengths and diameters ranging from $5 \mathrm{~m}$ to $20 \mathrm{~m}$ and $0.1 \mathrm{~m}$ to $0.3 \mathrm{~m}$, respectively and embedded in weak soil and resting on strong soil. In addition, the effect of post grouted on ultimate micropiles capacity are studied with different grouted length $\left(\mathrm{L}_{\mathrm{G}}\right)$ for micropiles type $\mathrm{D}$. The grouted length was taken as $(2,4 \ldots \ldots$. .etc. $) \mathrm{m}$ until all micropile length became post grouted, i.e. $\left(\mathrm{L}_{\mathrm{G}} / \mathrm{L}\right)=1.0$

The convincible shape used to simulate these micropiles in ABAQUS/CAE program are shown in Fig. (2). The magnitude of $(\alpha c)$ was chosen from 1.4 to 1.5 depending on the type of soil.

Table 1. Correction coefficient $\alpha_{c}$ for micropiles type D [6]

\begin{tabular}{|c|c|}
\hline Soil Type & $\boldsymbol{\alpha}_{\mathbf{c}}$ \\
\hline Gravel & 1.8 \\
\hline Sandy gravel & $1.6-1.8$ \\
\hline Gravely sand & $1.5-1.6$ \\
\hline Coarse sand & $1.4-1.5$ \\
\hline Medium sand & $1.4-1.5$ \\
\hline Fine sand & $1.4-1.5$ \\
\hline Silty sand & $1.4-1.5$ \\
\hline Silt & $1.4-1.6$ \\
\hline Clay & $1.8-2.0$ \\
\hline Marl & 1.8 \\
\hline
\end{tabular}

\section{Numerical models using ABAQUS I CAE program}

In ABAQUS/CAE, the block of model consists of parts, in this work two parts used to simulate the soilmicropiles system and the model is created with axisymmetric, deformable body with a shell, base feature.

The boundaries condition of this model extends in the lateral direction by a range equal $(10.5 \mathrm{D}), \mathrm{D}$, of micropile diameter from the centre of micropiles, and (L+10D), L, the length of micropiles below the tip in the vertical direction, [7]. Also, the boundary conditions assumed to be hinged at the end of the lower soil to prevent the horizontal and vertical movements, a roller inside of soils to allow a vertical movement and prevent horizontal movement, and symmetry/ antisymmetry / ancastre for the micropile's side.

Elasto - perfectly plastic model with Mohr Coulomb failure criterion, usually named as MohrCoulomb model, is widely used in finite element analysis of geotechnical engineering [8], [9], and [10]. In the present work, the Mohr-Coulomb criterion is used to simulate the soil material due to its simplicity and sufficient accuracy. Table (2) shows the properties of weak soils used in this study.

The micropile is modeled as linear elastic according to [11], [8], and [9]. The value of modulus of elasticity for the micropile is (14.2 GPa) according to [12], and the Poison's Ratio is assumed to be 0.2 .

Within a model, the sequence of one or more analysis steps can be defined. In this research, the steps must be used to analyze the behavior of a single pile embedded in weak soil including initial, geostatic and loading steps. The initial step, it allows defining boundary conditions, predefined field, and interactions that are applicable at the very beginning of the analysis. In the geostatic (First) step the gravity load is included, and the acceleration is specified to be $9.81 \mathrm{~m} / \mathrm{sec} 2$ in the vertical direction and zero in the horizontal direction, but the pressure loading applied in the pile top in the loading (second) step in high magnitude to reach to failure.

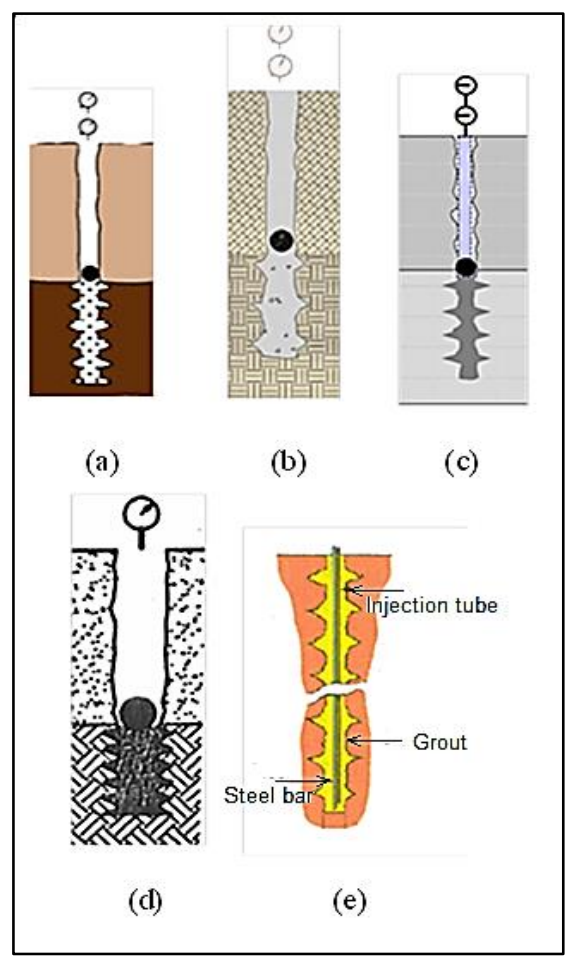

Fig.1. Suggested shapes of micropile type (D) by different Authors

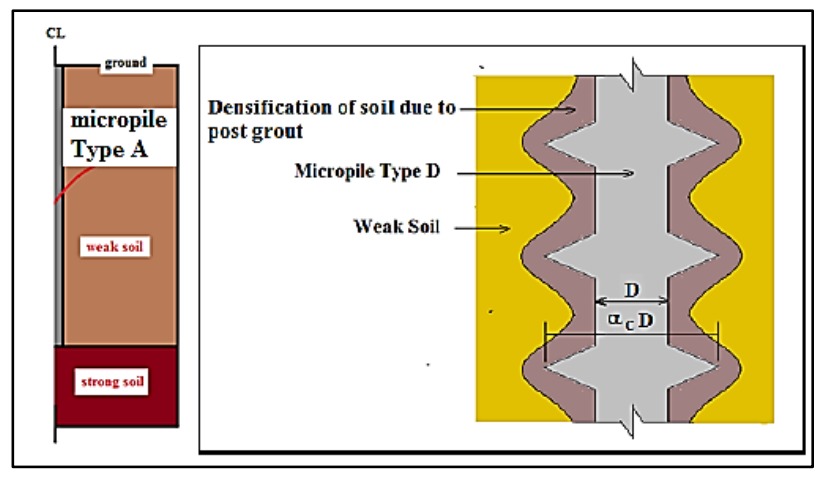

Fig. 2. Developed micropile type (D) and (A) model

\section{Interaction between micropiles and soils}

In this study, interface modeling has three steps:

- Defining the contact surfaces that could potentially be in contact.

Table 2. Soil Properties used in this Study 


\begin{tabular}{|c|c|c|c|c|}
\hline $\begin{array}{c}\text { Angle } \\
\text { of } \\
\text { Internal } \\
\text { Friction, } \\
\text { Ø० }\end{array}$ & Density & $\begin{array}{l}\text { Unite } \\
\text { weight, } \gamma \\
\mathrm{kN} / \mathrm{m}^{3}\end{array}$ & $\begin{array}{l}\text { Modulus } \\
\text { Elasticity of } \\
\text { Soil, Es } \\
\text { kN/m² }\end{array}$ & $\begin{array}{r}\text { Poisson's } \\
\text { ratio, } v\end{array}$ \\
\hline 25 & Loose & 15 & 25000 & 0.3 \\
\hline 30 & Medium & 16 & 37500 & 0.3 \\
\hline 35 & Dense & 17 & 50000 & 0.32 \\
\hline 40 & V. Dense & 18 & 80000 & 0.35 \\
\hline
\end{tabular}

- Starting which surfaces interact with one another (master and slave).

- Defining the mechanical and thermal properties of the surface (tangent and normal).

All the parts of the model are modelled using the Second-order continuum axisymmetric element (CAX4) with reduced order numerical integration available in ABAQUS (6.11).

In the surface based contact approach, two surfaces have to be defined based on their rigidity and the assignment of "master" and "slave" roles to the contact surfaces is used to model the interaction between micropile and soil, (Fig.3).

The contact behaviors at the pile-soil surface include load transfer mechanisms both in the normal and tangent direction. In this research a surface-to-surface contact with finite-sliding formulation was used to define the interaction between the micropile sides and the surrounding soil, the soil is assumed to be slave surface and the pile is master surface [13].

The friction along the pile shaft was found using Coulomb's friction law, [9], and [14]. The tangential behavior was defined using "penalty" friction formulation, with friction coefficient, $\mu$, and the shaft resistance stress is

$$
f_{s}=\mu \sigma_{x}^{\prime}=\sigma_{x}^{\prime} \tan \varphi_{i}^{\prime}
$$

\section{Where}

$\mu=$ the coefficient of friction

$\sigma_{x}^{\prime}=$ the lateral effective stress

$\varphi_{i}^{\prime}=$ the soil-pile interfacial effective friction angle.

"Hard" contact model was used to define contact pressure in normal behavior, [7].

\section{Ultimate capacity of micro piles type (D)}

Micropiles Type (D) constructed with post grouted pressure resulting with non-uniform diameters. Therefore, the skin friction increased leading to increasing the ultimate capacity. In this part, the ultimate capacity of micropiles type (D) is investigated. Also, the effect of grouted length $\left(\mathrm{L}_{\mathrm{G}}\right)$ on the increment of ultimate capacity is examined.

The typical load-settlement curves were found as shown in Fig. (4). The ultimate capacity for the micropile was established using the method proposed by [15], where the ultimate load can be determined as the abscissa part of the load-settlement curve changes to a falling straight line.
Figures (5) and (6) show the relationship between the ultimate capacity of micropiles with grouted length $\left(\mathrm{L}_{\mathrm{G}}\right)$, the grouted length is increased from zero (micropile Type (A)) with $2 \mathrm{~m}$ steps until the full length are grouted.

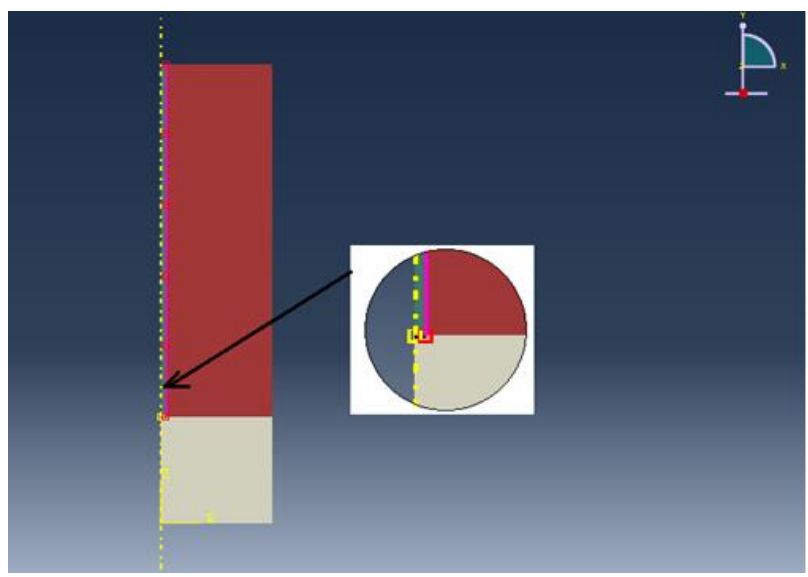

Fig. 3. Interaction between soil and micropiles

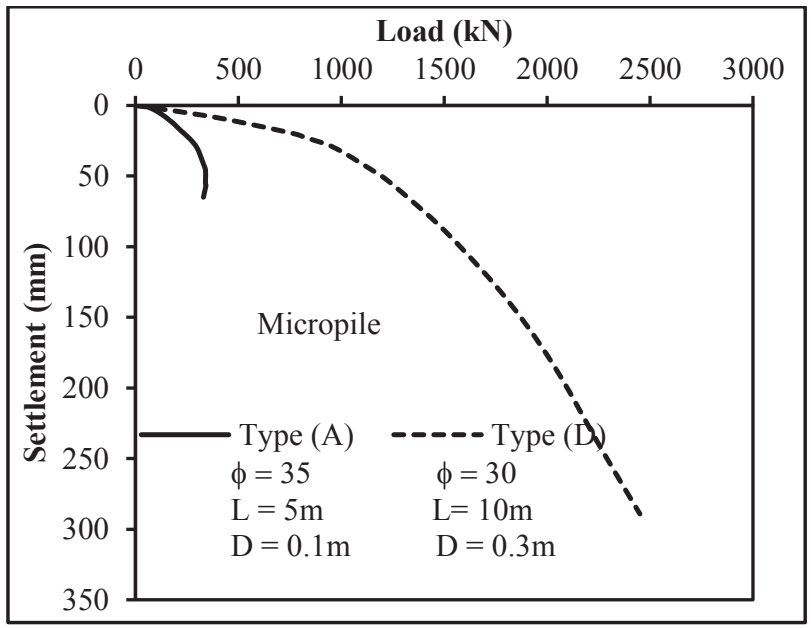

Fig. 4. Typical load - settlement curve obtained from the results for micropiles Type (A) and (D)

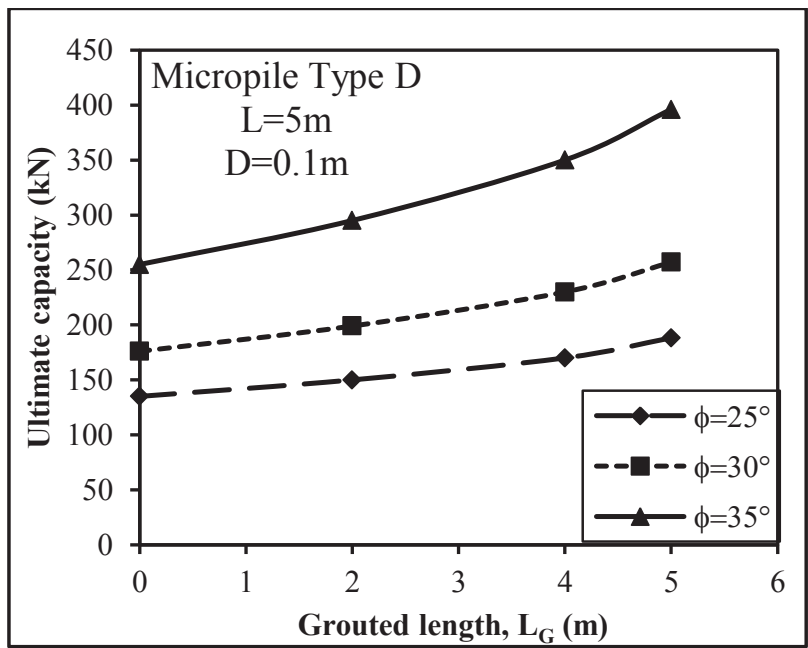

Fig. 5. Ultimate micropile capacity versus grouted length for different soil friction and constant diameter, $\mathrm{D}=0.1 \mathrm{~m}$ and length $=5 \mathrm{~m}$ 


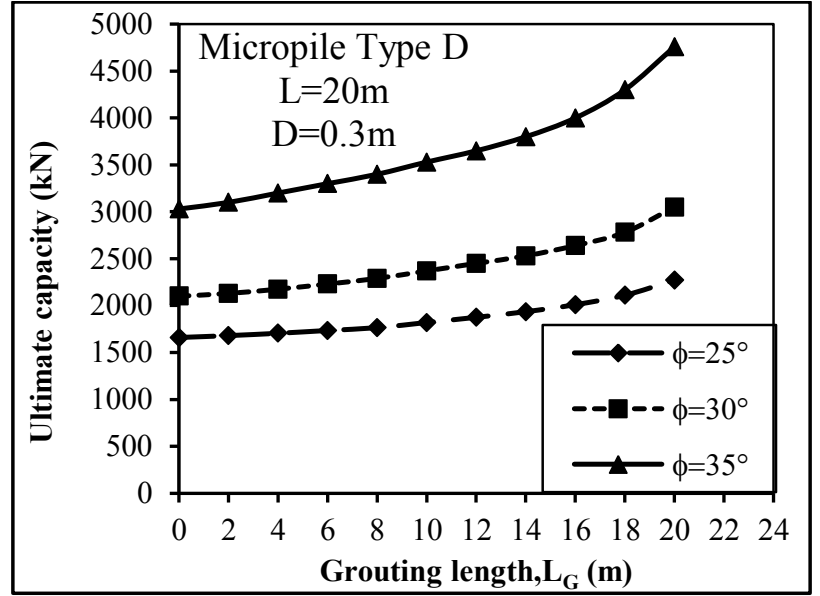

Fig. 6 Ultimate micropile capacity versus grouted length for different soil friction and constant diameter, $\mathrm{D}=0.1 \mathrm{~m}$ and length $=20 \mathrm{~m}$

The ultimate capacity of micropile increases as the grouted length increased, the trend of the curve notice to be linear when the grout length less than two third of the micropile length measured from the base. Then the trend became cone curve up; this behavior reflects the effect of the skin friction at the top layers of the soil, also the bonding zone length with toothed edges increases. Thus, it is recommended to post grouted full length of micropile to get better ultimate increment capacity. When the soil friction increased the effect of post grouted on the ultimate capacity are became pronounced more than less soil friction angle, herein the effect of interaction between the grouted cement and the soil increased led to increasing the shaft resistance and so on increased the ultimate capacity of micropile

\section{Ultimate capacity ratio of micro piles type (D)}

The ultimate capacity of micropile Type (D) was studied by using the ultimate capacity ratio for micropile type (D). This ratio represented the ultimate capacity of micropile grouted at different length to the ultimate capacity micropile type (A) at same length, diameter, and angle of internal friction of soil, (U.C.R) LG $_{\text {L }}$

Figures (7) to (18) show the relationship between the ultimate capacity ratio for micropile Type (D), (U.C.R $)_{\mathrm{LG}}$ and the grout length percentage $\left(\mathrm{L}_{\mathrm{G}} / \mathrm{L}\right)$. In these figures, the zero value of grout length percentage $\left(\mathrm{L}_{\mathrm{G}} / \mathrm{L}\right)$ at $\mathrm{x}$-axis represents micropile type (A). In these figures, the ultimate capacity ratio (U.C.R) LG $_{\text {increases }}$ as the grout length percentage increases; the increment is found to be running high as the $\left(\mathrm{L}_{\mathrm{G}} / \mathrm{L}\right) \%$ increases, where the bonding zone is increased. The value of the ultimate capacity ratio appears to be close to the grout length percentage not exceeding $20 \%$ for a different angle of internal friction of soil and micropile diameter.

The ultimate capacity is ratio increased by increasing the angle of soil friction increases. Also, the grouted pressure densify the soil around the micropile and lead to increasing the coefficient of earth pressure. Higher coefficients of earth pressure mean higher shaft capacity because of higher pressure exerted by the soil. The effect will be stronger for longer micropiles due to the increase in the effective stress of the soil.

In micropiles embedded in the weak soil, an increase in the length (L) resulted in a noticeable increase in the ultimate unit skin friction, as revealed in Table (3). For a length increase from $\mathrm{L}=5 \mathrm{~m}$ to $\mathrm{L}=20 \mathrm{~m}$ with a constant diameter $(0.1 \mathrm{~m})$, the ultimate capacity increased from $188 \mathrm{kN}$ to $684 \mathrm{kN}$, thus, an elevation of $73 \%$, and $264 \%$ for the same length increase but for micropile diameter $0.3 \mathrm{~m}$. Increasing might be due to an increase in the bonding pressure. For a certain micropile diameter, the ultimate capacity ratios give the impression to be much closed for micropiles with full grouted length, but for $\mathrm{L}_{\mathrm{G}} / \mathrm{L}$ less than $100 \%$ of these values are departed.

\section{Load transfer through soil for micro piles type (D)}

The load transfer behavior of micropile Type (D) embedded in weak soil and resting on the dense soil during loading is shown in Figure (19).

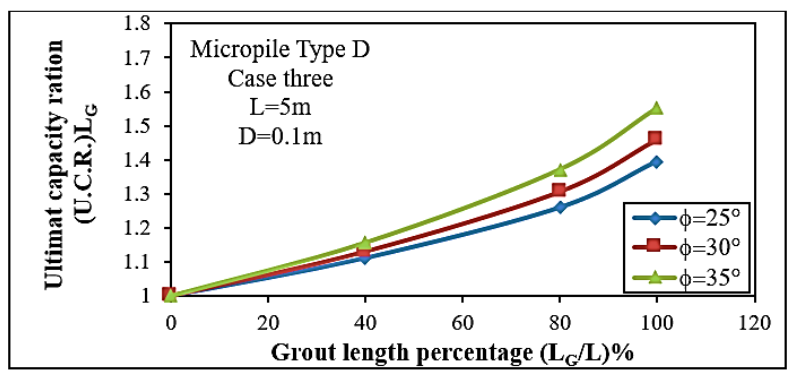

Fig. 7. Ultimate capacity ratio versus grout length percentage for micropile with $5 \mathrm{~m}$ length and $0.1 \mathrm{~m}$ diameter

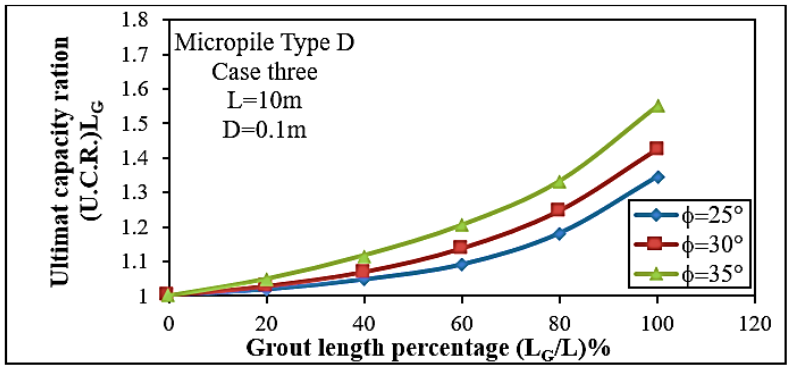

Fig. 8. Ultimate capacity ratio versus grout length percentage for micropile with $10 \mathrm{~m}$ length and $0.1 \mathrm{~m}$ diameter

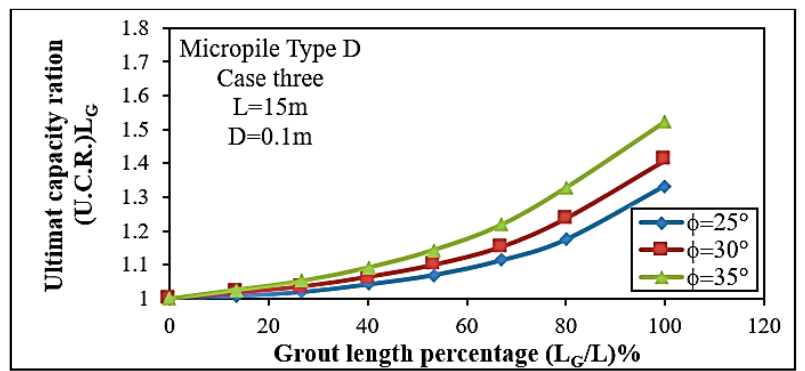


Fig. 9. Ultimate capacity ratio versus grout length percentage for micropile with $15 \mathrm{~m}$ length and $0.1 \mathrm{~m}$ diameter

It is clearly from this figure that skin resistance of the micropile shaft start to transfer the load to the surrounding soil and after the amount of loading increment the end bearing reaction start carrying the load. During loading the load transfer to the skin near the micropile then to the surrounding, soil far away. Before the failure, the shaft resistance is fully mobilized before the base resistance, but the load carrying by the latter is greater than that for micropile type (A).

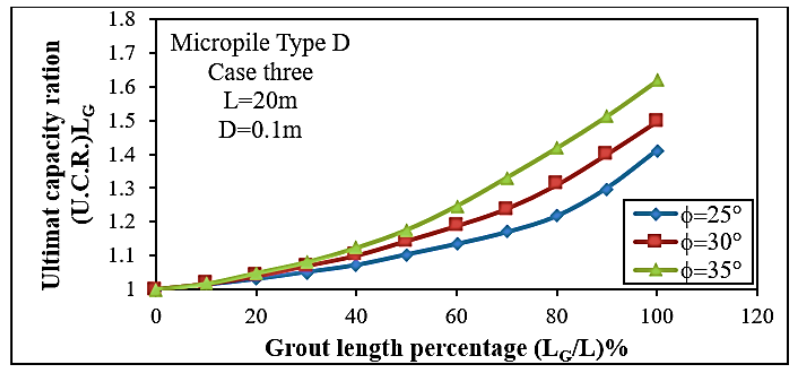

Fig. 10. Ultimate capacity ratio versus grout length percentage for micropile with $20 \mathrm{~m}$ length and $0.1 \mathrm{~m}$ diameter

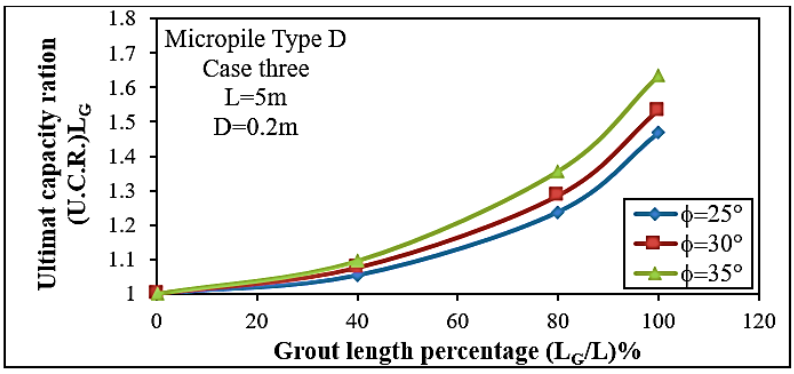

Fig. 11. Ultimate capacity ratio versus grout length percentage for micropile with $5 \mathrm{~m}$ length and $0.2 \mathrm{~m}$ diameter

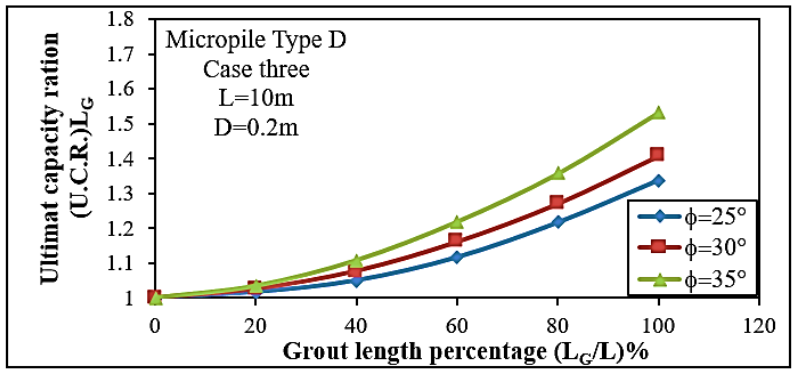

Fig. 12. Ultimate capacity ratio versus grout length percentage for micropile with $10 \mathrm{~m}$ length and $0.2 \mathrm{~m}$ diameter

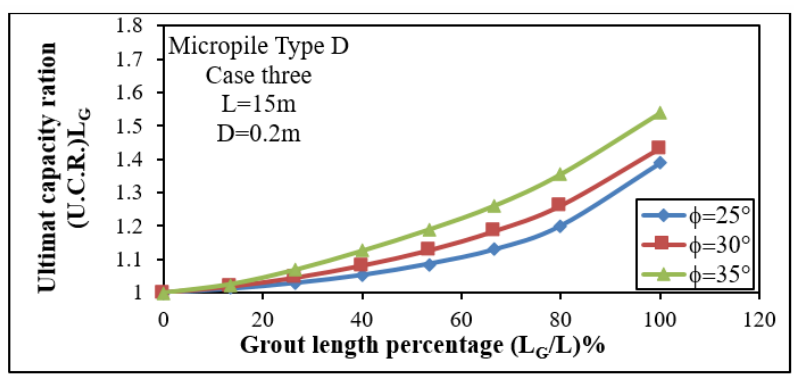

Fig. 13. Ultimate capacity ratio versus grout length percentage for micropile with $15 \mathrm{~m}$ length and $0.2 \mathrm{~m}$ diameter

\section{Conclusions}

Different behaviors are shown for Type (A) and Type (D), in terms of the mechanism of load transfer and the amount of load carrying capacity. In contrast, the effect of changing micropile length, diameter, and soil friction angle had given a similar behavior, where increasing any of these parameters increases the ultimate capacity of the micropile, with a different percentage.

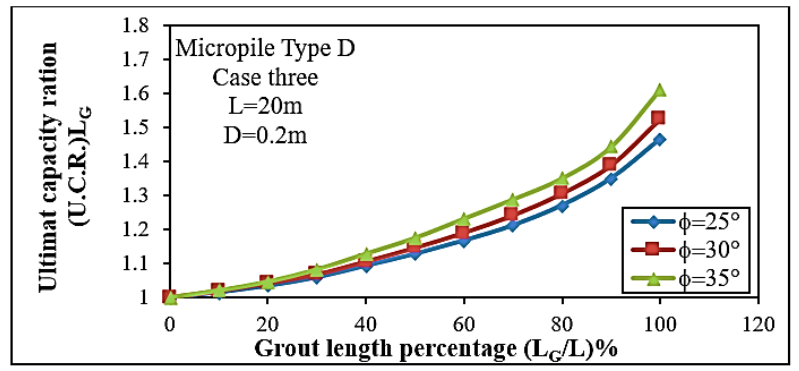

Fig. 14. Ultimate capacity ratio versus grout length percentage for micropile with $20 \mathrm{~m}$ length and $0.2 \mathrm{~m}$ diameter

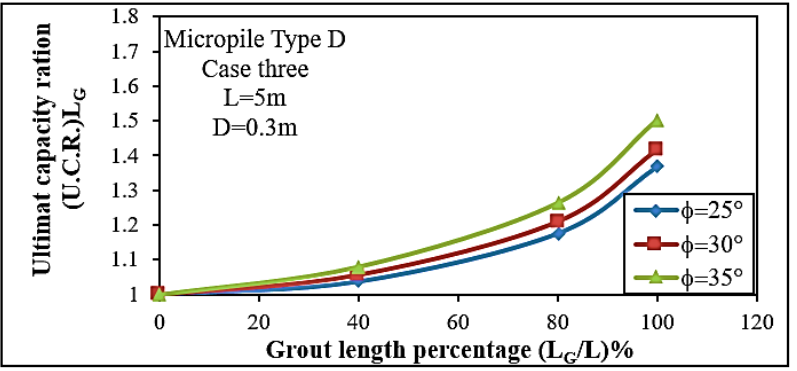

Fig. 15. Ultimate capacity ratio versus grout length percentage for micropile with $5 \mathrm{~m}$ length and $0.3 \mathrm{~m}$ diameter

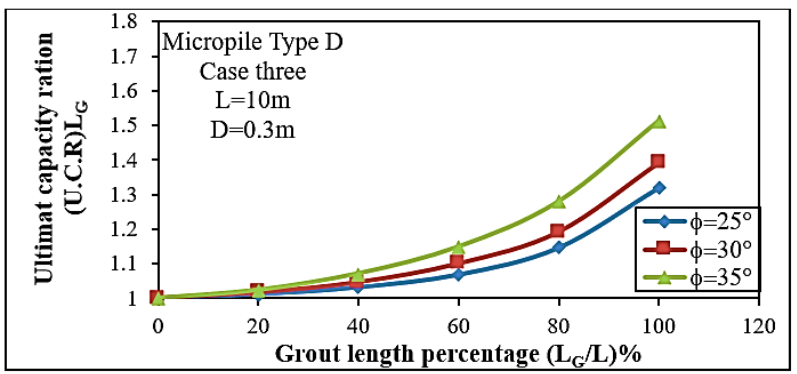

Fig. 16. Ultimate capacity ratio versus grout length percentage for micropile with $10 \mathrm{~m}$ length and $0.3 \mathrm{~m}$ diameter

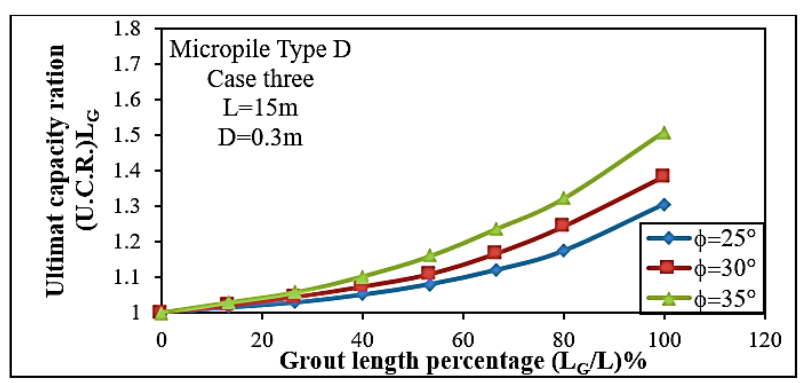


Fig. 17. Ultimate capacity ratio versus grout length percentage for micropile with $15 \mathrm{~m}$ length and $0.3 \mathrm{~m}$ diameter

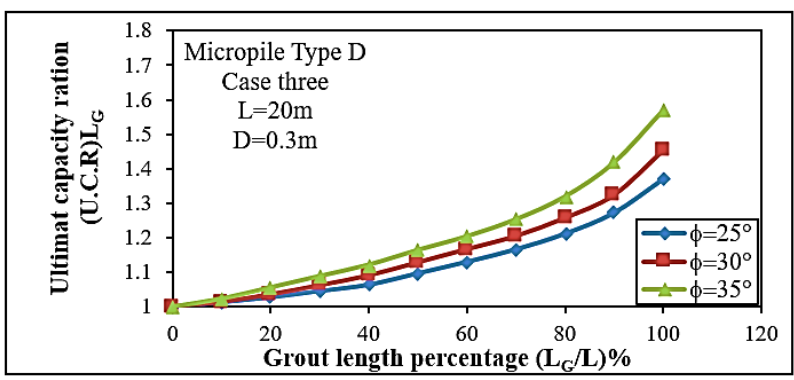

Fig. 18. Ultimate capacity ratio versus grout length percentage for micropile with $20 \mathrm{~m}$ length and $0.3 \mathrm{~m}$ diameter

It can be shown from the analysis results that the micropiles Type (D) gives the higher values of ultimate capacity as compared to micropiles Type (A). The ultimate capacities ratio for micropiles Type (D) ranges from (1.03) to (1.63) as compares with Type (A). Thus, it is preferable to the designer to think of employing micropile Type (D).

Table 3. Ultimate capacity of micropiles Type (D) (full grouted length)

\begin{tabular}{|c|c|c|c|}
\hline \multicolumn{2}{|c|}{ Micropile } & \multirow{2}{*}{$\begin{array}{c}\text { Angle of } \\
\text { Soil friction, } \\
\phi\left(^{\circ}\right)\end{array}$} & \multirow{2}{*}{$\begin{array}{c}\text { Ultimate } \\
\text { capacity, } \\
(\mathrm{kN})\end{array}$} \\
\hline $\begin{array}{l}\text { Length, } \\
\text { L (m) }\end{array}$ & $\begin{array}{l}\text { Diameter, D } \\
(\mathrm{m})\end{array}$ & & \\
\hline 5 & 0.1 & 25 & 188 \\
\hline 5 & 0.1 & 30 & 257 \\
\hline 5 & 0.1 & 35 & 396 \\
\hline 10 & 0.1 & 25 & 370 \\
\hline 10 & 0.1 & 30 & 520 \\
\hline 10 & 0.1 & 35 & 790 \\
\hline 15 & 0.1 & 25 & 533 \\
\hline 15 & 0.1 & 30 & 740 \\
\hline 15 & 0.1 & 35 & 1158 \\
\hline 20 & 0.1 & 25 & 684 \\
\hline 20 & 0.1 & 30 & 973 \\
\hline 20 & 0.1 & 35 & 1513 \\
\hline 5 & 0.2 & 25 & 431 \\
\hline 5 & 0.2 & 30 & 585 \\
\hline 5 & 0.2 & 35 & 940 \\
\hline 10 & 0.2 & 25 & 803 \\
\hline 10 & 0.2 & 30 & 1091 \\
\hline 10 & 0.2 & 35 & 1660 \\
\hline 15 & 0.2 & 25 & 1173 \\
\hline 15 & 0.2 & 30 & 1590 \\
\hline 15 & 0.2 & 35 & 2441 \\
\hline 20 & 0.2 & 25 & 1487 \\
\hline 20 & 0.2 & 30 & 2020 \\
\hline 20 & 0.2 & 35 & 3126 \\
\hline 5 & 0.3 & 25 & 674 \\
\hline 5 & 0.3 & 30 & 890 \\
\hline 5 & 0.3 & 35 & 1308 \\
\hline 10 & 0.3 & 25 & 1267 \\
\hline 10 & 0.3 & 30 & 1670 \\
\hline 10 & 0.3 & 35 & 2541 \\
\hline 15 & 0.3 & 25 & 1800 \\
\hline 15 & 0.3 & 30 & 2370 \\
\hline 15 & 0.3 & 35 & 3712 \\
\hline 20 & 0.3 & 25 & 2271 \\
\hline 20 & 0.3 & 30 & 3050 \\
\hline
\end{tabular}

\begin{tabular}{|l|l|l|l|}
\hline 20 & 0.3 & 35 & 4758 \\
\hline
\end{tabular}
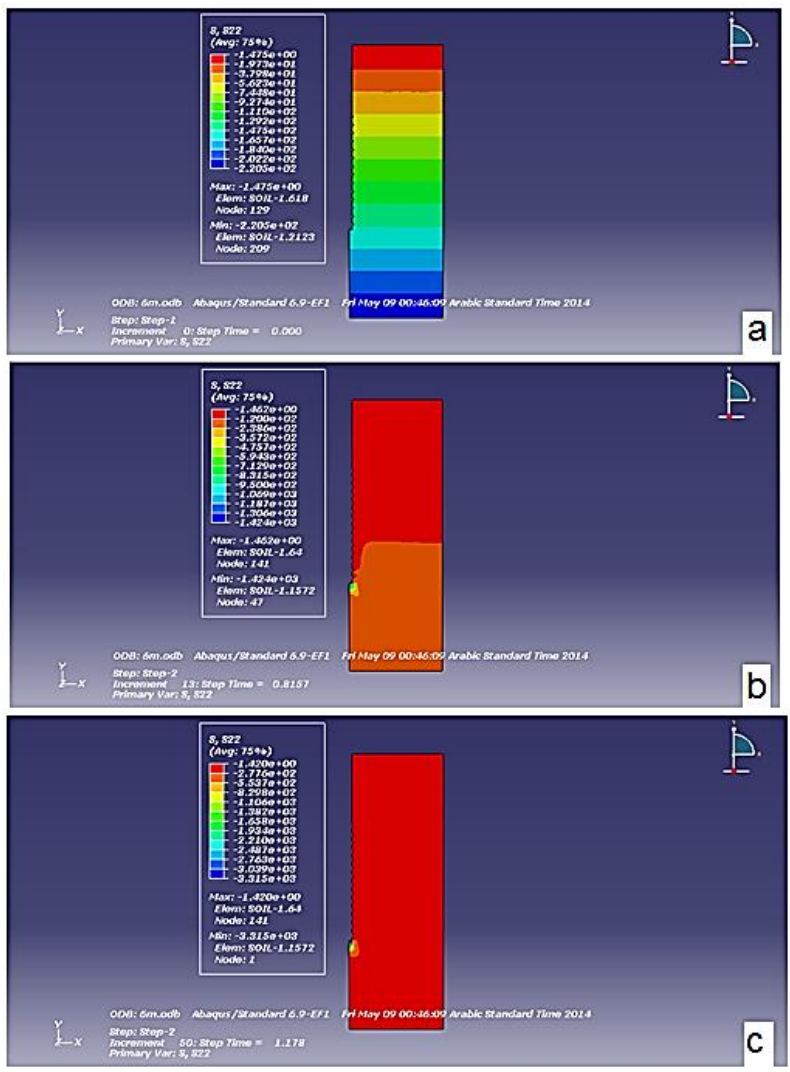

Fig. 19. Load transfer for micropile Type (D), (a) geostatic condition, (b) part of load applied, (c) before failure

\section{References}

1. FHWA, Micropiles Design and Construction Reference Manual, Sabatini, P.J., Tanya, B., Armour, T., Groneck, P. and Keely, J., Report No. FHWA-NHI-05-039, (2005).

2. J. Frassetto, C., Performance of Micropiles, M.Sc. Thesis, Concordia University, Canada, (2004).

3. A. Elsalfiti, K., Skin Friction of Micropiles Embedded in Gravelly Soils, M.Sc. Thesis, Concordia University, Canada, (2011).

4. D. Barron, Finite Element Modeling of Micropiles and the Influence of Steel Casing on Load Transfer Mechanisms, M.Sc. Thesis State University of New York at Buffalo, USA, (2016)

5. L. Shong, S. and F. Chung, C., Design and Construction of Micropiles, Geotechnical Course for Pile Foundation Design and Construction, pp: 149, (2003).

6. M. Bustamante, and B. Doix, A Method for Calculating Injected Anchors and Micropiles, Bull Liaison Lab. Highways, Paris, (1985)

7. Y. Zhan, H. Wang, and F. Liu, Modeling Vertical Bearing Capacity of Pile Foundation by using ABAQUS, EJGE, 17, pp. 1855-1865, (2012). 
8. G. Wang, and N. Sitar, Numerical Analysis of Piles in Elasto- Plastic Soils under Axial Loading, 17th ASCE Engineering Mechanics Conference, University of Delaware, Newark, pp: 8-14, (2004)

9. S. Salgado, M. Prezzi, and H. Seo, Advanced Modeling Tools for the Analysis of Axially Loaded Piles, Advances in Deep Foundation, International Workshop on Recent Advanced of Deep Foundations (IWDPF07), Port and Airport Research Institute, Yokosuka, Japan, (2007).

10. H. Seo, S. Jeong, and Y. Kim, Load Transfer Analysis of Rock-Socketed Drilled Shaft by Coupled Soil Resistance, Computer and Geotechnics, 36, Issue 3, April, pp: 446-453, (2009).

11. J. Lee, H., and R. Salgado, Determination of Pile Base Resistance in Sands, Journal of Geotechnical and Geoenvironmental Engineering, Vol. 125, No.8, pp: 673-683, (1999).

12. H. Elarabi, and M. Alhadi Alshareef, Estimation of Micropile Capacity Grouted Under Pressure, American Journal of Engineering, Technology and Society, Vol. 1, No. 2, pp. 11-14, (2014).

13. FHWA, Use of Micropiles for Foundations of Transportation Structures, Seo, H. and Prezzi, M., Final Report, FHWA/IN/JTRP-2008/18, (2008)

14. A. Stuedlein, W., M. Gibson, D. and G. Horvitz, E., Tension and Compression Micropile Load Tests in Gravelly Sand, 6th International Conference on Case Histories in Geotechnical Eng., Arlington, pp: $11-16,(2008)$ 